\title{
Dietary cation-anion difference could enhance acid-base status of lactating dairy cows submit to a subacidosis*
}

\author{
E. Apper-Bossard ${ }^{1}$ and J.-L. Peyraud \\ Department of Physiology and Agricultural Systems, \\ French National Institute of Agricultural Sciences \\ Domaine de la Prise, 35590 St-Gilles, France
}

\begin{abstract}
Dietary cation-anion difference (DCAD) affects animal performance (Tucker, 1988). To understand mechanisms involved, two groups of lactating fistulated cows received one of two concentrate levels (20 or $40 \% \mathrm{DM})$. Each group were assigned to two $3 \times 3$ Latin squares to test three DCAD $(0,150$ and 300 $\mathrm{mEq} / \mathrm{kg} \mathrm{DM}$ ) on performances, ruminal fluid and acid-base status. Feed intake and fat corrected milk yield were enhanced by increasing DCAD. Responses were greater with the high concentrate diet. Rumen $\mathrm{pH}$ and VFA were slightly affected by treatments while acid-base status was very responsive, suggesting that increasing DCAD improves performance through changes in acid-base status.
\end{abstract}

KEY WORDS: dietary cation-anion difference, acid-base status, subacidosis, lactating cows

\section{INTRODUCTION}

Increasing DCAD increases dairy cows performances (Tucker, 1988). Very few trials have been designed to examine how DCAD, described as $\mathrm{mEq}(\mathrm{Na}+\mathrm{K}-\mathrm{Cl}$ $\mathrm{S}) / \mathrm{kg}$ diet DM, could enhance performances. One of the possible explanation is that increasing $\mathrm{DCAD}$ enhances acid-base status. $\mathrm{Na}$ is absorbed from the gastrointestinal tract in exchange for the secretion of a proton whereas $\mathrm{Cl}$ is often absorbed from the gastrointestinal tract in exchange for the secretion of a bicarbonate ion. Conversely, increasing DCAD may improve ruminal activity. Furthermore, because increasing the rapidly degraded starch in the diet will increase the risk of appearance of subacidosis status, the DCAD effect could be more effective in diet rich in concentrate.

The objective of this trial was then to examine the effects of DCAD on acidbase physiology in lactating dairy cows fed at two different energetic rates.

\footnotetext{
* Supported by INZO, BP19 02402 Château-Thierry Cedex

${ }^{1}$ Corresponding author: e-mail: apper@st-gilles.rennes.inra.fr
} 
MATERIAL AND METHODS

Experimental design

Six midlactating Holstein cows equipped with a rumen canula were assigned to two groups of three cows according to stage of lactation, body weight, intake and milk production. Each group received one of two levels of concentrate $(20 \%$ $\mathrm{DM}$, diet "L" or $40 \% \mathrm{DM}$, diet " $\mathrm{H}$ ") during the entire experiment. Both groups were then assigned to a $3 \times 3$ Latin square design to test three different DCAD, 0 , 150 and $300 \mathrm{mEq} / \mathrm{kg}$ DM. Each period lasted 3-weeks.

\section{Treatments}

Cows were fed ad libitum (10\% refusals) with two complete rations based on maize silage. The $\mathrm{H}$ diet was formulated to present a greater acidogenic risk than the first through the inclusion of wheat and barley so that the readily degradable starch was $30.1 \%$ for $\mathrm{L}$ and $36.6 \%$ for $\mathrm{H}$.

The three different DCAD were achieved via manipulation of dietary $\mathrm{Na}$ and $\mathrm{Cl} . \mathrm{NH}_{4} \mathrm{Cl}$ was added to achieve $0 \mathrm{mEq} / \mathrm{kg} \mathrm{DN}$ and sodium carbonate was used to achieve $300 \mathrm{mq} / \mathrm{kg}$ DM. Sodium bicarbonate was not used to avoid the weel known buffer effect of bicarbonate in the rumen. Concentrations of the other minerals were kept constant to ensure that the physiological effects observed could be attributed to the manipulation of DCAD. The six treatments, noted L0, L150, L300 and H0, H150 and H300 have composed this experiment.

\section{Sample collection and analyses}

Intake and milk production were recorded daily. Milk samples were collected during six consecutive milkings and analysed for fat content. Blood, urine and rumen fluid samples were collected on the third weeks of each period to define the acid-base status, ruminal VFA and urinary minerals composition.

\section{Statistical analysis}

Data were analysed using the general linear models procedure of SAS according to the model for a split-plot design. The model included cow, period, concentrate level, DCAD, concentrate $\times$ period and concentrate $\times$ DCAD. Contrasts were measured for DCAD and concentrate by DCAD interactions. 


\section{RESULTS AND DISCUSSION}

There were no diseases during the experiment. All data were analysed. Daily feed intake increased with increasing DCAD. This response was stronger when cows were fed with diet $\mathrm{H}(+1.2 \mathrm{~kg} \mathrm{DM} / \mathrm{d}$ vs $+5.0 \mathrm{~kg} \mathrm{DM} / \mathrm{d} ; \mathrm{P}<0.05$, Table $1)$, confirming our hypothesis. These results were originally because of the interaction. Increasing DCAD increased fat corrected milk yield (Table 1).

Table 1. Intake, FCM, rumen $\mathrm{pH}$, acetate to propionate ratio and acid-base status of cows fed with different levels of concentrate and DCAD

\begin{tabular}{|c|c|c|c|c|c|c|c|c|c|}
\hline \multirow{2}{*}{ Sample } & \multirow{2}{*}{ Diet $^{2}$} & \multicolumn{3}{|c|}{$\mathrm{DCAD}^{1}$} & \multirow{2}{*}{ ETR } & \multirow{2}{*}{ ETR c } & \multicolumn{3}{|c|}{ Effects } \\
\hline & & 0 & 150 & 300 & & & Conc & DCAD & Conc $\times$ DCAD \\
\hline Feed intake & $\mathrm{L}$ & 19.6 & 20.4 & 20.8 & 0.63 & 4.40 & NS & $\mathrm{L}^{* *}$ & $\mathrm{~L}^{*}, \mathrm{Q}^{*}$ \\
\hline $\mathrm{kg} \mathrm{DM} / \mathrm{d}$ & $\mathrm{H}$ & 20.7 & 21.2 & 25.7 & & & & & \\
\hline FCM & $\mathrm{L}$ & 29.3 & 32.6 & 33.8 & 1.63 & 15.20 & NS & $\mathrm{L}^{*}$ & NS \\
\hline $\mathrm{kg} / \mathrm{d}$ & $\mathrm{H}$ & 29.7 & 31.1 & 37.5 & & & & & \\
\hline \multirow[t]{2}{*}{ Rumen $\mathrm{pH}$} & $\mathrm{L}$ & 6.12 & 6.39 & 6.28 & 0.110 & 0.123 & $*$ & NS & NS \\
\hline & $\mathrm{H}$ & 6.05 & 5.94 & 6.17 & & & & & \\
\hline \multirow[t]{2}{*}{ Range of $\mathrm{pH}$} & $\mathrm{L}$ & 0.66 & 0.61 & 0.81 & 0.359 & 0.406 & NS & NS & NS \\
\hline & $\mathrm{H}$ & 0.96 & 0.91 & 0.88 & & & & & \\
\hline \multirow[t]{2}{*}{$\mathrm{C}_{2} / \mathrm{C}_{3}$} & $\mathrm{~L}$ & 2.69 & 2.76 & 3.06 & 1.064 & 1.089 & NS & NS & NS \\
\hline & $\mathrm{H}$ & 2.71 & 1.95 & 2.44 & & & & & \\
\hline \multirow[t]{2}{*}{ Blood pH } & $\mathrm{L}$ & 7.40 & 7.41 & 7.43 & 0.010 & 0.025 & NS & $\mathrm{L}^{* *}$ & $\mathrm{~L}^{*}$ \\
\hline & $\mathrm{H}$ & 7.36 & 7.40 & 7.44 & & & & & \\
\hline \multirow{4}{*}{$\begin{array}{l}\mathrm{HCO}_{3} \\
\mathrm{mmol} / 1 \\
\mathrm{SBE}^{3} \\
\mathrm{mmol} / 1\end{array}$} & $\mathrm{~L}$ & 22.9 & 25.8 & 27.5 & 1.18 & 2.18 & NS & $\mathrm{L}^{* *}$ & NS \\
\hline & $\mathrm{H}$ & 21.0 & 23.8 & 26.5 & & & & & \\
\hline & $\mathrm{L}$ & -1.43 & 1.40 & 3.00 & 1.16 & 2.28 & NS & $\mathrm{L}^{* *}$ & NS \\
\hline & $\mathrm{H}$ & -3.70 & -0.67 & 2.22 & & & & & \\
\hline Urinary $\mathrm{Na}$ & $\mathrm{L}$ & 24.1 & 22.4 & 100.2 & 36.8 & 16.1 & NS & $\mathrm{L}^{*}$ & NS \\
\hline $\mathrm{mEq} / 1$ & $\mathrm{H}$ & 13.4 & 25.0 & 98.9 & & & & & \\
\hline Urinary $\mathrm{Cl}$ & $\mathrm{L}$ & 227.4 & 89.0 & 26.1 & 25.2 & 19.4 & NS & $\mathrm{L} * *$ & NS \\
\hline $\mathrm{mEq} / 1$ & $\mathrm{H}$ & 209.3 & 120.6 & 56.2 & & & & & \\
\hline \multirow[t]{2}{*}{ Urinary $\mathrm{pH}$} & $\mathrm{L}$ & 6.59 & 8.32 & 8.46 & 0.350 & 0.841 & NS & $\mathrm{L}^{* *}$ & NS \\
\hline & $\mathrm{H}$ & 6.42 & 7.57 & 8.42 & & & & & \\
\hline
\end{tabular}

${ }^{1}$ dietary cation-anion difference, expressed as $\mathrm{mEq} / \mathrm{kg} \mathrm{DM}(\mathrm{Na}+\mathrm{K})-(\mathrm{Cl}+\mathrm{S})$

${ }^{2}$ diet L: "Low concentrate", 20\% DM; Diet H: "High concentrate", 40\% DM

${ }^{3} \mathrm{SBE}$ means Standard Base Excess which is an indicator of alkaline stores

L: linear effect, Q: quadratic effect

${ }^{\dagger}<0.10 ; * \mathrm{P}<0.05 ; * * \mathrm{P}<0.01$ 
Feeding $\mathrm{H}$ diet decreased ruminal $\mathrm{pH}$ and numerically decreased the $\operatorname{diet} \mathrm{C}_{2}: \mathrm{C}_{3}$ (Table 1). This indicates that the $\mathrm{H}$ diet increased the rate of ruminal fermentation. Increasing DCAD did not affect significantly affect ruminal $\mathrm{pH}$, range of $\mathrm{pH}$ decrease during the mean and the $\mathrm{C}_{2}: \mathrm{C}_{3}$ ratio (Table 1). This results differ from those described when sodium bicarbonate was added to the diet (Erdman, 1988) and indicates that DCAD had only marginal effect on ruminal fermentations.

Increasing DCAD increased blood $\mathrm{pH}$, bicarbonates concentration and $\mathrm{SBE}$ and the increase of blood $\mathrm{pH}$ was more important with $\mathrm{H}$ diet than with $\mathrm{L}$ diet (Table 1). These results suggest that increasing DCAD improves cows performance mainly by influencing homeostatic metabolism. Increasing DCAD increased urinary $\mathrm{pH}$, urinary $\mathrm{Na}$ (Table 1). Decreasing DCAD increased urinary $\mathrm{Cl}$. With a low DCAD, cows excreted $\mathrm{H}^{+}$and $\mathrm{Cl}^{-}$in order to limit blood $\mathrm{pH}$ decrease, explaining the low urinary $\mathrm{pH}$. In the same time, they kept $\mathrm{Na}^{+}$to regulate blood $\mathrm{pH}$. Inversely, with increasing DCAD thus $\mathrm{Na}$ intake, cows excreted $\mathrm{Na}^{+}$.

\section{CONCLUSIONS}

Increasing DCAD enhances high producing dairy cows performances when they were fed with a high concentrate diet. Like the effect of increasing DCAD tended to be highest when cows were fed with the more acidogen diet, we can reasonably assume that increasing DCAD could be used to prevent subacidosis apparition.

\section{REFERENCES}

Erdman R.A., 1988. Dietary buffers requirements of the lactating cows : a review. J. Dairy Sci. 71, 3246-3266

Tucker W.B., Harrison G.A., Hemken R.W., 1988. Influence of dietary cation-anion balance on milk, blood, urine and rumen fluid in lactating dairy cattle. J. Dairy Sci. 71, 346-35 